\title{
OPINIA CIEZŻARNYCH NA TEMAT KOMPETENCJI POŁOŻNYCH W ASPEKCIE PROWADZENIA CIĄŻY FIZJOLOGICZNEJ
}

\section{OPINION OF PREGNANT WOMEN ABOUT THE COMPETENCE OF MIDWIVES IN THE ASPECT OF THE PHYSIOLOGICAL PREGNANCY CARE}

\author{
Anna Leja-Szpak ${ }^{1}$, Katarzyna Bulanda ${ }^{2}$, Jolanta Jaworek ${ }^{1}$ \\ ${ }^{1}$ Zakład Fizjologii Medycznej, Instytut Fizjoterapii, Wydział Nauk o Zdrowiu \\ Uniwersytet Jagielloński - Collegium Medicum \\ ${ }^{2}$ absolwentka kierunku: położnictwo, Wydział Nauk o Zdrowiu \\ Uniwersytet Jagielloński - Collegium Medicum
}

DOI: https://doi.org/10.20883/pielpol.2018.13

\section{STRESZCZENIE}

Wstęp. Od zarania dziejów ciężarnymi i rodzącymi opiekowały się inne kobiety. Początkowo te mające doświadczenie i powszechny szacunek w plemieniu, z czasem - wykształcone akuszerki. Do końca XIX w. był to zawód samodzielny z uwagi na postrzeganie ciąży jako procesu fizjologicznego. W konsekwencji nadmiernej medykalizacji społeczeństwo zaczęło postrzegać ją jako proces wymagający interwencji medycznej. Położne utraciły samodzielność zawodową, natomiast opiekę nad ciężarną i rodzącą przejęli lekarze. Zgodnie $\mathrm{z}$ "Rozporządzeniem Ministra Zdrowia z dnia 23 września 2010 r. (...)" położne mają zagwarantowaną możliwość prowadzenia ciąży fizjologicznej.

Cel. Poznanie opinii ciężarnych na temat kompetencji zawodowych położnych, głównie w aspekcie prowadzenia przez nie ciąży fizjologicznej.

Materiał i metody. Badania przeprowadzono wśród ciężarnych hospitalizowanych w jednym ze szpitali krakowskich. Zastosowano metodę sondażu diagnostycznego, za narzędzie badawcze postużył autorski kwestionariusz ankiety. Analizie poddano 105 ankiet.

Wyniki. Badania wykazały, że aż $61 \%$ respondentek nie było świadomych, że położna może prowadzić ciążę fizjologiczną. Nawet po otrzymaniu tej informacji zaznaczyły one, iż nie zrezygnowałyby z prowadzenia ciąży przez ginekologa na rzecz położnej (67\%). Argumentowały to przekonaniem o niewystarczającej wiedzy położnych dotyczącej ciąży, porodu, połogu $(41,6 \%)$ oraz ich nieodpowiednim przygotowaniem do opieki nad ciężarną (36,1\%). Ankietowane, które wiedziały o tej możliwości (39\%), czerpały wiedzę głównie z nieprofesjonalnych źródeł informacji.

Wnioski. Pomimo istnienia regulacji prawnych w zakresie kompetencji położnych, zwłaszcza w aspekcie prowadzenia ciąży fizjologicznej, do rozwiązania pozostaje problem niekorzystnego postrzegania tego zawodu przez społeczeństwo i wynikających z tego ograniczeń w samodzielności zawodowej.

SŁOWA KLUCZOWE: ciąża fizjologiczna, kompetencje zawodowe położnych, standard opieki położniczej.

\begin{abstract}
Introduction. Pregnant and parturient women have been carried for other women since the dawn. Initially, these having experience and widespread respect in the tribe, later educated in that direction midwife. By the end of the nineteenth century, the profession of midwery was independent because of the perception of pregnancy as a physiological process. Later, the society have come to the conclusion, that this process that requires medical intervention. It was a consequence of excessive medicalization of patients care. Midwives have lost their professional independen$\mathrm{ce}$, and doctors took care on the pregnant and parturient women. According to the 'Minister of Health of 23 September 2010 on standards of conduct and medical procedures (...) in the field of perinatal care (...)' midwives are guaranteed the ability to conduct physiological pregnancy.

Aim. To recognize the opinion of pregnant on the professional competence of midwives, mainly in terms of the conduct of their physiological pregnancy.

Material and methods. The study was conducted among pregnant women hospitalized in a one of hospital of Krakow. The research tool was the original questionnaire. 105 questionnaires have been analyzed.

Results. The study showed that $61 \%$ of respondents were not aware that a professional midwife can conduct physiological pregnancy. Even after receiving this information, they have indicated that they do not resigned of the pregnancy conduction by the gynecologist (67\%). Argued that the conviction of insufficient knowledge of midwives on pregnancy, childbirth, postpartum (41.6\%) and their inadequate preparation for the care of pregnant women (36.1\%). The interviewee who were aware of this possibility (39\%) drew their knowledge mainly from non-professional sources of information such as the Internet or familiar.

Conclusions. Despite the existence of relevant legal regulations in the competence of midwives, especially in the context of the pregnancy physiological, to solve the problem remains unfavorable perception of the profession by the public and the resulting restrictions on self-employment.
\end{abstract}

KEYWORDS: physiological pregnancy, professional competence of midwives, maternity care standard. 


\section{Wprowadzenie}

\section{Rola położnej na przestrzeni wieków}

Pierwsze działania medyczne (30 tys. lat p.n.e.) związane były z przyjmowaniem porodu, a potrzeba udzielania pomocy rodzącej wynikała samoistnie, na podstawie doświadczenia [1, 2]. Opieka nad ciężarną i rodzącą sprawowana była przez kobiety. Do porodów wzywano te cieszące się powszechnym szacunkiem w plemieniu, a położnictwo opierało się głównie na mistycyzmie, przesądach i zabobonach. Wszelkich niepowodzeń w tym zakresie dopatrywano się w siłach nadprzyrodzonych [3]. Również w starożytności położnictwem zajmowały się kobiety. W Egipcie czy Mezopotamii położne potrafiły wykonywać rękoczyny w przypadku nieprawidłowego ułożenia płodu oraz chronić krocze przed pęknięciem. W przypadku śmierci płodu wykonywały tzw. zabiegi pomniejszające umożliwiające jego wydobycie. Zajmowały się także leczeniem chorób kobiecych [2-4]. W kulturze słowiańskiej położne określano jako „mądre baby” lub „baby”. Z kolei w rzymsko-germańskiej nazywano je feminae sapientes (łac.) i weise Frauen (germ.), czyli „mądre kobiety”. Dopiero w połowie XV w. pojawiło się określenie: akuszerka [1, 3]. Średniowiecze było okresem regresu dla położnych. Odstąpiono od dotychczasowych metod na rzecz ziołolecznictwa i alchemii [2-4]. W XVI w., oprócz opieki nad ciężarną, rodzącą i położnicą, z uwagi na panujące w tym czasie liczne zarazy, położne udzielały się jako edukatorki w zakresie przeciwdziałania zakażeniom. Ponadto miały za zadanie rozpoznawanie, czy znaleziony martwy noworodek zmarł w trakcie porodu, czy w łonie matki lub czy kobieta była w ciąży w przypadku podejrzenia o aborcję lub dzieciobójstwo. Położna mogła także w razie konieczności wykonać cięcie cesarskie u umierającej lub zmarłej kobiety celem ratowania dziecka [5]. Od połowy XVII w. już nie tylko kobieta mogła sprawować opiekę nad rodzącą, ale i mężczyzna miał taką możliwość. Wynikało to z dominacji mężczyzn w medycynie i wsparcia ze strony Kościoła. Zaczęły powstawać placówki, w których mogły kształcić się położne. Mimo uprawnień nie posiadały one narzędzi położniczych, którymi dysponował lekarz lub mężczyzna - położny. Z tego powodu położne odsunięto od przyjmowania porodów patologicznych. Od tamtej pory zaczęły zajmować się wyłącznie fizjologiczną ciążą i porodem $[5,6]$. Na przełomie XIX i XX w. w większości krajów zaczęto wydawać rozporządzenia określające prawa i obowiązki położnych, a równocześnie lekarze domagali się przekazania im opieki nad kobietą rodzącą. Mimo to położne nadal przyjmowały porody, a medyków wzywano tylko w razie komplikacji. W 1884 r. w Berlinie powstał pierwszy w Europie związek zawodowy położnych, a 2 lata później zaczęto wydawać pierwsze czasopismo dla położnych [3].

\section{Rola i kształcenie położnych w Polsce}

Pierwsze doniesienia na temat opieki nad kobietą w okresie okołoporodowym w Polsce pochodzą z XIII w., kiedy to biskup Pełka (Fulko) sprowadził do Krakowa wiedeńskich zakonników - „braci szpitalnych”. Idąc jego śladem, biskup krakowski Jan Prandota wybudował szpital z kościołem Świętego Ducha, powierzając braciom opiekę nad kalekami, ciężarnymi, położnicami i dziećmi. Szpital spełniał funkcję dobroczynną i religijną, nie prowadził natomiast kształcenia lekarzy ani akuszerek [6]. Do końca XVIII w. opieka nad ciężarną, rodzącą i położnicą spoczywała na zakonnikach w szpitalach oraz wspomnianych już „babkach” lub „mądrych”. To od tych ostatnich adeptki uczyły się zawodu. „Babki” nie potrafiły pisać ani czytać, dlatego nie mogły korzystać z pojawiających się ksiąg o tematyce położniczej [6, 7]. W okresie porozbiorowym zaczęły powstawać szkoły dla położnych. Początkowo nie był to zawód prestiżowy. Kandydatki na położne pochodziły z ubogich rodzin, nie potrafiły czytać ani pisać. $Z$ upływem czasu podjęto działania mające na celu poprawę procesu edukacji i poziomu nauczania. Przyszłe położne musiały spełniać określone wymagania oraz zdawać egzaminy teoretyczne i praktyczne. Bardzo ważne były także ich postawa moralna, poświęcenie i oddanie pracy oraz zdrowie fizyczne i inteligencja [7, 8]. Po zakończeniu II wojny światowej ranga zawodu położnych wzrosła. W trakcie rekrutacji do szkół położniczych, prócz wyników z egzaminów wstępnych, zwracano uwagę na pochodzenie i status majątkowy przyszłych adeptek [7, 8]. W drugiej połowie XX w. wprowadzono nowe nazewnictwo i podział szkół położnych - wydziały położnych w medycznych studiach zawodowych. Miały one własne statuty działalności. Cykl kształcenia podzielono na semestry, określono liczbę słuchaczek oraz prowadzenie ćwiczeń i zajęć praktycznych w niewielkich grupach [8]. Na początku XXI w. (lata 2000-2003), zgodnie z założeniami Deklaracji Bolońskiej, zmienił się system kształcenia położnych w Polsce. Wprowadzono trzy poziomy kształcenia: ukończone uzyskaniem tytułu licencjata, magistra, doktora. Obecnie położne są kształcone na poziomie akademickim, a ich dyplom uznawany jest w krajach Unii Europejskiej [6, 8]

\section{Cele pracy}

Celem badań było poznanie opinii ciężarnych na temat kompetencji zawodowych położnych, szczególnie w aspekcie prowadzenia przez nie ciąży fizjologicznej. Do celów szczegółowych należały: 
- określenie świadomości ankietowanych o możliwości prowadzenia ciąży fizjologicznej przez położną oraz ustalenie źródeł informacji na badany temat,

- $\quad$ określenie odsetka kobiet korzystających z usług położnych w zakresie prowadzenia ciąży fizjologicznej,

- poznanie opinii badanych na temat zalet i wad prowadzenia ciąży fizjologicznej przez położną,

- określenie roli personelu medycznego i placówek medycznych w informowaniu ciężarnych o możliwości prowadzenia ciąży fizjologicznej przez położną.

\section{Materiał i metody}

Badania przeprowadzono wśród ciężarnych hospitalizowanych w Szpitalu Uniwersyteckim w Krakowie na przełomie 2015/2016 r. W badaniu wykorzystano metodę sondażu diagnostycznego, a za narzędzie badawcze posłużył autorski kwestionariusz ankiety. Analizie poddano 105 kwestionariuszy. Dane zebrano w arkuszu kalkulacyjnym Microsoft Excel 2003 oraz dokonano analizy jakościowej.

\section{Wyniki}

Najliczniejszą grupę wiekową (62,9\%) spośród badanych stanowiły ciężarne między 26. a 35. r.ż. W przedziale od 19 do 25 lat znalazło się 21,9\% ankietowanych, powyżej 35. r.ż. - 14,3\% ciężarnych, natomiast w przedziale 18 lat i mniej - 0,9\%. W 70,5\% badane miały wykształcenie wyższe, w 22,8\% - wykształcenie średnie, a w 6,7\%-zawodowe. Najwięcej ankietowanych, tj. 55\%, było w pierwszej ciąży. Dla $21 \%$ była to druga ciąża, a dla $20 \%$ - trzecia. Jako osobę prowadzącą ciążę $78,1 \%$ ankietowanych wskazało lekarza ze specjalizacją z ginekologii i położnictwa, a 21\% kobiet - lekarza ginekologa (I stopień specjalizacji). Ciążę 1 ankietowanej nadzorowała położna. Analiza procentowa jednoznacznie wskazuje, że w badanej grupie ciąże były prowadzone przez osoby inne niż położna.

Ważnym czynnikiem determinującym wybór osoby do prowadzenia ciąży może być jej przebieg, jak również przebieg wcześniejszych ciąż i porodów. Z tego względu zapytano ciężarne o występowanie u nich choroby/chorób przewlekłych i tak 81,9\% respondentek zadeklarowało brak takiej choroby, a spośród pozostałych: 52,6\% cierpiało na niedoczynność tarczycy, 15,8\% - na chorobę Hashimoto oraz po $10,5 \%$ - na nadciśnienie tętnicze i cukrzycę. Większość (88,6\%) ankietowanych odpowiedziała, że obecna ciąża przebiega prawidłowo.

U $21 \%$ ankietowanych pojawiły się w trakcie ciąży komplikacje (pytanie wielokrotnego wyboru), a były to: infekcje grypopodobne (31,7\%), plamienie/krwawienie z pochwy, infekcje dróg moczowych (22,7\%), cukrzyca ciężarnych $(18,2 \%)$, niedokrwistość, cholestaza ciążowa, infekcje dróg rodnych (po 9,1\%) i inne. Również 70\% ciężarnych uznało, że poprzednie ciąże przebiegały prawidłowo. Wśród pozostałych $30 \%$ odpowiedzi wskazujących na powikłany przebieg poprzedniej/ poprzednich ciąż najwięcej dotyczyło poronienia. Inne osoby wskazywały na plamienie/krwawienie z pochwy (20\%), anemię ciężarnych (15\%), nadciśnienie indukowane ciążą (5\%) i inne. Ponadto $85 \%$ badanych ciężarnych nie doświadczyło powikłań w trakcie poprzedniego/poprzednich porodów i/lub w okresie poporodowym.

Zasadnicza część ankiety dotyczyła zagadnień związanych z kompetencjami położnych. Większość ankietowanych (62\%) wskazała studia pierwszego stopnia (licencjat) jako szkołę nadającą uprawnienia do wykonywania zawodu położnej. Pięćdziesiąt procent pytanych zaznaczyło odpowiedź: studia drugiego stopnia (magisterskie), a 40\% - szkołę medyczną (studium medyczne). Kurs położniczy wskazało 19\% respondentek (pytanie wielokrotnego wyboru).

Sześćdziesiąt jeden procent ankietowanych było świadomych faktu, że zawód położnej jest zawodem samodzielnym, z kolei 39\% uznało, że położna w swoich działaniach w pełni zależy od lekarza.

Ankietowane poproszono o wskazanie, które spośród wymienionych kompetencji w zakresie prowadzenia ciąży, porodu i opieki w połogu należą do położnej (pytanie wielokrotnego wyboru). W odpowiedzi $90,5 \%$ osób wskazało na wykonanie badania kardiotokograficznego płodu, $77,1 \%$ - na prowadzenie porodu fizjologicznego, a 71,4\% - na przyjmowanie porodu fizjologicznego. Respondentki zaznaczyły także odpowiedzi nienależące do kompetencji położnej, takie jak przebicie pęcherza płodowego, wykonywanie badania USG płodu, prowadzenie ciąży powikłanej, wykonywanie badań prenatalnych i wykonanie cięcia cesarskiego.

Znajomość podstawowych kompetencji położnych miało potwierdzić kolejne pytanie dotyczące tylko jednej z tych kompetencji, tj. możliwości prowadzenia ciąży fizjologicznej przez położną w Polsce. Najwięcej ankietowanych (61\%) udzieliło w tym zakresie odpowiedzi przeczącej. Tylko 39\% kobiet wiedziało, że położna może prowadzić ciążę fizjologiczną.

Ankietowane, które były świadome, że położne mają możliwość prowadzenia ciąży fizjologicznej, wskazały także źródła informacji (Tabela 1). Opierając się na wynikach analizy procentowej, można założyć, że były to głównie źródła internetowe $(56,1 \%)$ oraz w mniejszym stopniu szkoły rodzenia (29,3\%), telewizja i czasopisma dla kobiet (po 26,8\%). 
Tabela 1. Źródła wiedzy ankietowanych o możliwości prowadzenia ciąży fizjologicznej przez położną (dane nie sumują się do 100\%, ponieważ było to pytanie wielokrotnego wyboru)

Table 1. Sources of participant's knowledge regarding the possibility of conducting normal pregnancy by a midwife (the data does not add up to $100 \%$ since it was a multiple choice question)

\begin{tabular}{cccc}
\hline Odpowiedzi ankietowanych/Respondents' answers & $\mathrm{n}$ & $\%$ \\
\hline $\begin{array}{c}\text { Internet (strony internetowe, blogi, social media)/Internet } \\
\text { (websites, blogs, social media) }\end{array}$ & 23 & 56,1 \\
Szkoły rodzenia/Antenatal classes & 12 & 29,3 \\
\hline Telewizja/TV & 11 & 26,8 \\
\hline Pisma dla kobiet/Journals for women & 11 & 26,8 \\
\hline Poradnia K (ginekologiczna)/Gynecological clinic & 9 & 21,9 \\
Szpital/Hospital & 9 & 21,9 \\
\hline Pisma medyczne/Medical journals & 6 & 14,6 \\
\hline Inne: wiedziałam od zawsze/Other: I've always known & 1 & 2,4 \\
\hline Inne: nie pamiętam/Other: I do not remember & 1 & 2,4 \\
\hline Inne: dowiedziałam się na studiach/Other: / learned in & 1 & 2,4 \\
college & 1 & 2,4 \\
\hline Inne: dowiedziałam z ankiety/Other: / learned from the \\
survey
\end{tabular}

Źródło: opracowanie własne

Source: author's own analysis

Tabela 2. Osoby będące źródłem wiedzy ankietowanych o możliwości prowadzenia ciąży fizjologicznej przez położną (pytanie wielokrotnego wyboru)

Table 2. Participants who responded regarding the possibility of conducting a normal pregnancy by a midwife (the multiple choice question)

\begin{tabular}{ccc}
\hline Odpowiedzi ankietowanych/Respondents' answers & $\mathrm{n}$ & $\%$ \\
\hline Znajome/Familiar & 17 & 41,5 \\
Położna/Midwife & 15 & 36,6 \\
Rodzina/Family & 8 & 19,5 \\
Lekarz ginekolog/Gynecologist & 5 & 12,2 \\
Inne: nie pamiętam/Other: I do not remember & 1 & 2,4 \\
Inne: własne doświadczenie/Other: own experience & 1 & 2,4 \\
\hline
\end{tabular}

Źródło: opracowanie własne

Source: author's own analysis

Kolejnym ważnym aspektem dotyczącym źródeł badanych informacji było wskazanie przez ciężarne osoby informującej. Najwięcej razy padała odpowiedź: znajome (41,5\%), nieco mniej, gdyż 36,6\%, ankietowanych wskazało położną, a 12,2\% - lekarza ginekologa (Tabela 2).

Tylko 2 respondentki zdeklarowały, że ich aktualną i/lub poprzednią/poprzednie ciąże prowadziła położna. Ciężarne nie podjęły tej decyzji same, lecz po wskazaniu im takiej możliwości przez położną czy znajomych. Obydwie ciężarne wyraziły zadowolenie z podjętej decyzji.

Analizując deklarowane przez respondentki preferencje odnośnie ewentualnej rezygnacji z prowadzenia ciąży przez lekarza na rzecz prowadzenia ciąży przez położną (pod warunkiem, że ciąża przebiegałaby fizjologicznie), wykazano, że aż 69\% kobiet nie zdecydowałoby się na taką zmianę. Spośród tych ankietowanych najwięcej $(41,6 \%)$ uzasadnia swoje stanowisko niewy- starczającą wiedzą położnej dotyczącą ciąży, porodu, połogu, a 36,1\% kobiet wskazuje na brak odpowiedniego przygotowania położnej (Tabela 3).

Tabela 3. Argumenty przeciwko rezygnacji z prowadzenia ciąży przez lekarza na rzecz położnej (pytanie wielokrotnego wyboru)

Table 3. Arguments against having the midwife conduct the pregnancy as opposed to the doctor (the multiple choice question)

\begin{tabular}{ccc}
\hline Odpowiedzi ankietowanych/Respondents' answers & $n$ & $\%$ \\
\hline $\begin{array}{c}\text { Położna nie ma wystarczającej wiedzy dotyczącej ciąży, po- } \\
\text { rodu, połogu/The midwife does not have enough knowledge }\end{array}$ & 30 & 41,6 \\
about pregnancy, childbirth, puerperium & & \\
$\begin{array}{c}\text { Położna nie jest osobą odpowiednio przygotowaną do opieki } \\
\text { nad ciężarną/The midwife is not adequately educated for the } \\
\text { care of the pregnant woman }\end{array}$ & 36,1 \\
$\begin{array}{c}\text { Położna nie ma możliwości wystawiania zwolnień z pracy } \\
\text { i skierowań na bezpłatne badania laboratoryjne (badania }\end{array}$ & \\
trzeba wykonać odpłatnie)/The midwife is not allowed to issue & 21 & 29,2 \\
layoffs and referrals for free laboratory tests (tests must be \\
$\quad$ made for a fee)
\end{tabular}

Źródło: opracowanie własne

Source: author's own analysis

Tabela 4. Argumenty za rezygnacją z prowadzenia ciąży przez lekarza na rzecz położnej (pytanie wielokrotnego wyboru)

Table 4. Arguments for having the midwife conduct the pregnancy as opposed to the doctor (the multiple choice question)

\begin{tabular}{ccc}
\hline Odpowiedzi ankietowanych/Respondents' answers & $\mathrm{n}$ & $\%$ \\
\hline $\begin{array}{c}\text { Położna jest osobą odpowiednio przygotowaną do opieki } \\
\text { nad ciężarną/A midwife is a person adequately prepared } \\
\text { to care for the pregnant }\end{array}$ & 26 & 78,8 \\
$\begin{array}{c}\text { Położna ma niezbędną wiedzę dotyczącą ciąży, porodu, } \\
\text { połogu/Midwives have the necessary knowledge about } \\
\text { pregnancy, childbirth, puerperium }\end{array}$ & 21 & 63,6 \\
$\begin{array}{c}\text { Mam zaufanie do położnych/I trust the midwives } \\
\text { Man }\end{array}$ & 15 & 45,5 \\
\hline
\end{tabular}

Źródło: opracowanie własne

Source: author's own analysis

Wśród 31\% respondentek, które zrezygnowałyby z prowadzenia ciąży fizjologicznej przez lekarza na rzecz prowadzenia ciąży przez położną, 78,8\% uważa, że położna jest osobą odpowiednio przygotowaną do opieki nad ciężarną, a 63,6\% jest zdania, że położna ma niezbędną wiedzę dotyczącą ciąży, porodu, połogu (Tabela 4). Do innych argumentów należały: tańsze 
prowadzenie ciąży przez położną, zaangażowanie i indywidualne podejście położnej do ciężarnej, brak tendencji medykalizacji porodu oraz deklaracja zmiany lekarza prowadzącego ciążę na położną pod warunkiem finansowania wizyt u położnej przez NFZ i możliwości skierowań na bezpłatne badania. Pomimo powyższej argumentacji 59\% badanych nie dostrzega korzyści związanych z prowadzeniem ciąży fizjologicznej.

Tabela 5. Korzyści z prowadzenia ciąży fizjologicznej przez położną (pytanie wielokrotnego wyboru)

Table 5. Benefits of conducting a normal pregnancy by a midwife (the multiple choice question)

\begin{tabular}{ccc}
\hline Odpowiedzi ankietowanych/Respondents' answers & $n$ & $\%$ \\
\hline $\begin{array}{c}\text { Możliwość zdobycia wiedzy na temat karmienia piersią/ } \\
\text { Opportunity to gain knowledge about breastfeeding }\end{array}$ & 39 & 90,1 \\
$\begin{array}{c}\text { Możliwość zdobycia wiedzy na temat opieki nad noworodkiem/ } \\
\text { Opportunity to gain knowledge about infant care }\end{array}$ & 39 & 90,1 \\
$\begin{array}{c}\text { Możliwość zdobycia wiedzy na temat ciąży, porodu, połogu/ } \\
\text { Opportunity to gain knowledge about pregnancy, childbirth, } \\
\text { postpartum }\end{array}$ & 33 & 76,7 \\
$\begin{array}{c}\text { Nauka zachowania w trakcie porodu/Learning to behave } \\
\text { during labor }\end{array}$ & 31 & 72,1 \\
\hline $\begin{array}{c}\text { Zmniejszenie lęku związanego z porodem/Reducing the } \\
\text { anxiety associated with childbirth }\end{array}$ & 31 & 72,1 \\
\hline $\begin{array}{c}\text { Poczucie bezpieczeństwa i komfort psychiczny/Sense of } \\
\text { security and mental comfort }\end{array}$ & 20 & 46,5 \\
\hline $\begin{array}{c}\text { Pewność i ciągłość opieki w ciąży, podczas porodu, } \\
\text { w połogu/Certainty and continuity of care during pregnancy, } \\
\text { childbirth, postpartum }\end{array}$ & 15 & 34,9 \\
\hline $\begin{array}{c}\text { Brak konieczności uczęszczania do szkoły rodzenia/No need } \\
\text { to attend antenatal }\end{array}$ & 12 & 27,9 \\
\hline
\end{tabular}

Źródło: opracowanie własne

Source: author's own analysis

Jak wynika z tabeli 5, najwięcej ankietowanych $(90,1 \%)$ dostrzegających korzyści związane z prowadzeniem ciąży fizjologicznej przez położną zaznaczyło odpowiedź: możliwość zdobycia wiedzy na temat karmienia piersią oraz opieki nad noworodkiem. Ciężarne wskazywały także na możliwość zdobycia wiedzy na temat ciąży, porodu, połogu (76,7\%), naukę zachowania w trakcie porodu oraz zmniejszenie lęku związanego z porodem (po 72,1\% ankietowanych).

Wśród odpowiedzi 30\% kobiet dostrzegających wady wynikające $z$ prowadzenia ciąży fizjologicznej padały: niewystarczająca wiedza i przygotowanie medyczne w razie wystąpienia powikłań ciąży $(45,16 \%)$, brak wystarczających kwalifikacji do prowadzenia ciąży fizjologicznej (19,35\%), brak umiejętności do wykrywania wad płodu (9,67\%), lecz także: niemożność wykonywania USG przez położną, wystawiania skierowań na bezpłatne badania oraz wypisywania recept, wypisywania przez położną zwolnienia z pracy czy nawet niemożność wykonania przez położną cięcia cesarskiego (Tabela 6).
Tabela 6. Wady wynikające z prowadzenia ciąży fizjologicznej przez położną (pytanie wielokrotnego wyboru)

Table 6. Disadvantages of conducting a normal pregnancy by a midwife (the multiple choice question)

\begin{tabular}{|c|c|c|}
\hline Odpowiedzi ankietowanych/Respondents' answers & $\mathrm{n}$ & $\%$ \\
\hline $\begin{array}{l}\text { Niewystarczająca wiedza i przygotowanie medyczne w razie } \\
\text { wystapienia powikłań ciąży/lInsufficient knowledge and prepa- } \\
\text { ration in the event of medical complications of pregnancy }\end{array}$ & 14 & 45,16 \\
\hline $\begin{array}{l}\text { Brak wystarczających kwalifikacji do prowadzenia ciąży fizjo- } \\
\text { logicznej/Inadequate qualification for physiological pregnancy } \\
\text { conducting }\end{array}$ & 6 & 19,35 \\
\hline $\begin{array}{l}\text { Niemożność wykrycia wad płodu w badaniu USG/Inability to } \\
\text { detect fetal defects in ultrasound }\end{array}$ & 3 & 9,67 \\
\hline $\begin{array}{l}\text { Obawa przed nierozpoznaniem przez położną ewentualnych } \\
\text { nieprawidłowościl/Fear of not being diagnosed by the midwife }\end{array}$ & 3 & 9,67 \\
\hline Niemożność wykonywania USG/Inability to perform ultrasound & 2 & 6,45 \\
\hline $\begin{array}{l}\text { Niemożność wystawiania skierowań na bezpłatne badania/The } \\
\text { inability to issue free referrals }\end{array}$ & 2 & 6,45 \\
\hline $\begin{array}{c}\text { Niemożność wypisywania recept przez położną)/Inability } \\
\text { prescription by a midwife }\end{array}$ & 2 & 6,45 \\
\hline $\begin{array}{c}\text { Niemożność wypisywania zwolnienia z pracy/Inability to issue } \\
\text { dismissal }\end{array}$ & 1 & 3,22 \\
\hline $\begin{array}{l}\text { Niemożność wykonania przez położną cięcia cesarskiego/ } \\
\text { Impossibility of caesarean section by the midwife }\end{array}$ & 1 & 3,22 \\
\hline
\end{tabular}

Brak dostrzegania korzyści przez ciężarne z prowadzenia ciąży przez położną oraz wskazywanie przez nie licznych wad mogących wynikać z tego stanu znalazły potwierdzenie w negatywnej opinii (71\%) odnośnie zwiększenia zakresu kompetencji zawodowych położnych, tzn. wykonywania przez nie zadań, które w Polsce należą wyłącznie do lekarza.

Tabela 7. Czynniki mogące mieć wpływ na częstsze korzystanie przez ciężarne w Polsce z usług położnych w prowadzeniu ciąży fizjologicznej (pytanie wielokrotnego wyboru)

Table 7. Factors that may affect the frequent use of the midwife services to conduct a normal pregnancy among the pregnant in Poland (the multiple choice question)

\begin{tabular}{|c|c|c|}
\hline Odpowiedzi ankietowanych/Respondents' answers & $\mathrm{n}$ & $\%$ \\
\hline $\begin{array}{c}\text { Kampanie informacyjne w mediach na temat możliwości prowa- } \\
\text { dzenia ciąży fizjologicznej przez położną/Information campaigns } \\
\text { in the media about the possibility of carrying out physiological } \\
\text { gestation by the midwife }\end{array}$ & 52 & 85,2 \\
\hline $\begin{array}{l}\text { Gabinety położnych w okolicy umożliwiające korzystanie z ich usług/ } \\
\text { Offices of midwives in the area allow you to use their services }\end{array}$ & 43 & 70,5 \\
\hline $\begin{array}{l}\text { Większa świadomość kobiet w ciąży o prawach położnych/ } \\
\text { Increased awareness of pregnant women about the rights of midwives }\end{array}$ & 36 & 59 \\
\hline $\begin{array}{l}\text { Większa świadomość położnych dotycząca przysługujących im praw/ } \\
\text { Increased awareness of midwives regarding their rights }\end{array}$ & 16 & 26,2 \\
\hline $\begin{array}{c}\text { Inne: przekazywanie informacji przez lekarza/kierowanie ciężar- } \\
\text { nej do położnej/Other: information transfer by a doctor/directing } \\
\text { a pregnant woman to a midwife }\end{array}$ & 1 & 1,6 \\
\hline $\begin{array}{c}\text { Inne: możliwość uzyskanie informacji na ten temat w szpitalach } \\
\text { i przychodniach/Other: information on this in hospitals and } \\
\text { outpatient clinics }\end{array}$ & 1 & 1,6 \\
\hline
\end{tabular}

Źródło: opracowanie własne

Source: author's own analysis 
Brak konieczności zwiększania kompetencji zawodowych położnych wskazało $71 \%$ ankietowanych, jednakże pozostałe respondentki zaznaczyły, że istnieją czynniki, które wpłynęłyby na częstsze korzystanie przez ciężarne w Polsce z usług położnych w zakresie prowadzenia ciąży fizjologicznej. Mogłoby to być organizowanie kampanii informacyjnych w mediach na ten temat $(85,2 \%)$ oraz lokalnego reklamowania gabinetów położnych z uwzględnieniem zakresu ich kompetencji (70,5\%). Ankietowane wskazywały także na konieczność budowania większej świadomości kobiet w ciąży o prawach położnych, możliwości uzyskiwania informacji na ten temat w szpitalach i przychodniach czy od lekarza.

\section{Dyskusja}

Do końca XIX w. zawód położnej był zawodem całkowicie samodzielnym. Uważano ciążę i poród u zdrowej kobiety za proces całkowicie naturalny. Zachodzący w drugiej połowie XX w. proces nadmiernej medykalizacji porodu niekorzystnie wpłynął na pozycję zawodową położnych, ograniczając ich dotychczasową samodzielną działalność. Położne stały się „średnim personelem” medycznym, a kobiety rodzące przestały cenić ich umiejętności [1-3, 9].

W ostatnich latach w Polsce podjęto próby przywrócenia położnym samodzielności i poprawienia ich pozycji zawodowej. Odbywa się to m.in. dzięki wsparciu Naczelnej Rady Pielęgniarek i Położnych, Polskiego Towarzystwa Położnych, Fundacji Rodzić po Ludzku oraz samych położnych, które rozumieją konieczność promowania swojego zawodu. Ponadto modyfikacja polskiego prawa daje położnym dostęp do szkolnictwa wyższego, przeprowadzania badań naukowych oraz informacji pozwalających im poszerzać swoją wiedzę i umiejętności $[9,10]$.

Obowiązująca aktualnie „Ustawa z dnia 15 lipca 2011 r. o zawodach pielęgniarki i położnej" zawiera informacje na temat wykształcenia, jakie powinna posiadać osoba na tym stanowisku, zapewnia położnym samodzielność oraz szczegółowo określa ich prawa i obowiązki [9]. Na podstawie uzyskanych wyników badań można stwierdzić, że badane ciężarne są zorientowane, jakie wykształcenie powinna mieć położna, aby wykonywać swój zawód. Ponadto większość z nich, tj. $61 \%$, wie, że jest to zawód samodzielny, czyli niezależny od lekarza w zakresie posiadanych uprawnień zawodowych. Zgodnie z obowiązującym prawem położna uzyskuje kwalifikacje zawodowe po ukończeniu szkoły położnych, prowadzącej aktualnie kształcenie na poziomie studiów licencjackich (pierwszego stopnia) i magisterskich (drugiego stopnia). Zawód mogą wykonywać także osoby, które wcześniej ukończyły szkołę policealną lub pomaturalną kształcącą w zawodzie położnej [9].
Jak wykazała analiza kwestionariuszy, studia pierwszego stopnia wskazało $62 \%$ ciężarnych, studia drugiego stopnia - 50\%, a szkołę medyczną (studium medyczne) $-40 \%$. Do kompetencji położnych należą promocja zdrowia oraz udzielanie samodzielnych świadczeń zapobiegawczych, pielęgnacyjnych, diagnostycznych, leczniczych, rehabilitacyjnych względem ciężarnych, rodzących, położnic i kobiet w różnych okresach życia, a także noworodków. Wykonywanie zawodu obejmuje także pracę dydaktyczną, naukowo-badawczą w zakresie położnictwa oraz pracę na stanowiskach kierowniczych [9-11].

Jak wykazano w badaniach, ankietowane potrafią wskazać kompetencje zawodowe położnych w zakresie prowadzenia porodu i opieki w połogu. Niestety większość z respondentek (61\%) uważa, że położna w Polsce nie może prowadzić ciąży fizjologicznej. Co więcej - równie znaczący statystycznie odsetek badanych (69\%) nie zrezygnowałby z prowadzenia ciąży przez lekarza na rzecz prowadzenia jej przez położną, nawet pod warunkiem fizjologicznego przebiegu ciąży. Ciężarne argumentowały swą decyzję brakiem wystarczającej wiedzy położnych na temat ciąży, porodu, połogu $(41,6 \%)$ oraz niewystarczającym przygotowaniem medycznym (36,1\%). Nieco mniejszy, choć równie ważny problem stanowiła także kwestia ekonomiczna: niemożność wystawiania zwolnień z pracy i skierowań na bezpłatne badania $(29,2 \%)$ oraz brak finansowania wizyt u położnej przez NFZ (6,9\%).

Tymczasem od 23 września 2010 roku, zgodnie z "Rozporządzeniem Ministra Zdrowia (...) w sprawie standardu postępowania przy udzielaniu świadczeń zdrowotnych z zakresu opieki okołoporodowej sprawowanej nad kobietą w okresie fizjologicznej ciąży, fizjologicznego porodu, połogu oraz opieki nad noworodkiem", położna ma prawo prowadzić ciążę fizjologiczną i oznacza to, że w tym zakresie posiada kompetencje na równi z lekarzem [12].

Według standardu położna „zajmuje się” wyłącznie ciążą fizjologiczną, czyli taką, która przebiega w sposób prawidłowy [12]. W trakcie ciąży kobieta jest kierowana średnio trzy razy do lekarza ginekologa celem przeprowadzenia badań ultrasonograficznych (USG) płodu. Położna może także zlecić wykonanie dodatkowych badań profilaktycznych lub diagnostycznych w przypadku, gdy stan zdrowia ciężarnej lub poprzednie wyniki wskazują na możliwość wystąpienia powikłań w ciąży, podczas porodu i połogu. W przypadku wystąpienia któregoś z czynników ryzyka, określonych w standardzie, położna ma obowiązek skierowania ciężarnej do szpitala o odpowiednim do jej stanu zdrowia stopniu referencyjności [12]. Niniejsze stanowisko otrzymało silne poparcie organizacji międzynarodowych. Na początku grudnia 2014 r. niezależna brytyjska 
instytucja NICE (ang. National Institute for Health and Care Excellence), tworząca standardy w zapobieganiu i leczeniu chorób [13], zaleciła, by ciąże i porody niskiego ryzyka były prowadzone wyłącznie przez położne [14]. Z kolei badania przeprowadzone w University of Minnesota School of Public Heath i opublikowane w lutym 2015 r. w „Maternal and Child Journal” pokazują, że opieka położnej nad kobietą w ciąży fizjologicznej prowadzi do lepszej komunikacji między ciężarną i rodzącą a personelem medycznym, co stanowi fundament prawidłowej opieki nad ciężarną i rodzącą [15]. Stąd można wnioskować, że obawy respondentek odnośnie jakości prowadzenia opieki przez położną, ich wiedzy i kwalifikacji nie są słuszne. Najprawdopodobniej wynikają z niewiedzy w zakresie tego tematu oraz powszechnego problemu nadmiernej medykalizacji - zjawiska występującego w każdej dziedzinie medycyny, zwłaszcza w ginekologii i położnictwie. Naturalne zdarzenia z życia ludzkiego, takie jak np. ciąża czy poród, postrzegane są jako nieprawidłowości, wymagające diagnozy i szczególnej kontroli lekarskiej [16, 17]. Świadczy o tym fakt, że najwięcej ankietowanych $(78,1 \%)$ wskazało jako osobę prowadzącą ich ciążę lekarza ze specjalizacją z ginekologii i położnictwa. Tylko 2 respondentki zadeklarowały, że ich aktualną i/lub poprzednią ciążę prowadziła położna.

Spośród respondentek świadomych możliwości prowadzenia ciąży fizjologicznej przez położne ponad połowa $(56,1 \%)$ jako źródło tej wiedzy wskazała Internet. Znacznie rzadziej dowiadywały się o takiej możliwości ze szkoły rodzenia (29,3\%), szpitala czy poradni K (po 21,9\% kobiet). Natomiast osobami stanowiącymi źródło badanej wiedzy respondentek były przede wszystkim znajome $(41,5 \%)$, następnie położne $(36,6 \%)$, rodzina (19,5\%) czy lekarz ginekolog (12,2\%). Wyniki jasno pokazują, że to nie placówki medyczne i personel medyczny stanowią źródło wiedzy o możliwości prowadzenia ciąży fizjologicznej przez położną, ale przede wszystkim Internet i znajome. Może być to przyczyną zdobywania nierzetelnej wiedzy oraz kształtowania się niewłaściwych opinii i postaw względem położnych.

Pomimo istnienia ustaw określających kompetencje położnych i gwarantujących im samodzielność lekarze oraz społeczeństwo nie zawsze postrzegają je jako członków jednego zespołu terapeutycznego. Często uważa się, że są one podwładnymi lekarzy, podczas gdy w rzeczywistości powinny być partnerami i współpracownikami. Wieloletnie ograniczenie samodzielności zawodowej położnych wpłynęło negatywnie na postrzeganie ich przez społeczeństwo oraz przez nie same. Wiele położnych przyzwyczaiło się do wykonywania wyłącznie „poleceń” lekarzy i nie korzysta z obecnie gwarantowanej samodzielności i możliwości dalszego kształcenia [9]. Grychtoł i Leszczyńska poruszają ten problem w swoim artykule „Stereotypy a pozycja zawodowa". [18]. Na przykładzie grupy zawodowej pielęgniarek przedstawiają przypisane im „łatki” od czasu Il wojny światowej. Określenie: pomocnice lekarza, czyli personel pomocniczy, wyraźnie pokazuje ich podporządkowanie oraz zależność i bynajmniej nie kojarzy się z podejmowaniem samodzielnych decyzji czy możliwością samorozwoju. Ich rola sprowadzana jest do wykonywania zleceń lekarskich, a profesjonalizm oceniany jest przez pryzmat umiejętności technicznych [18].

Obecnie polskie położne mają praktycznie te same kompetencje zawodowe, co ich koleżanki w większości krajów europejskich, ale tam zawód ten cieszy się powszechnym szacunkiem i prestiżem, a prowadzenie przez nie ciąż fizjologicznych jest ogólnie przyjętą normą. Ponadto położne w niektórych krajach posiadają więcej kompetencji zawodowych - być może przez to ich samodzielność jest bardziej zauważalna niż w Polsce. Np. we Francji położne wykonują badania USG [19]. Podobnie jest w Danii, gdzie położne prowadzą wraz z lekarzem specjalistą ciąże wysokiego ryzyka (np. ciąże bliźniacze lub ciąże kobiet uzależnionych) [20, 21]. Niestety badane ciężarne nie widzą potrzeby zwiększania kompetencji zawodowych położnych.

Zgodnie z "Ustawą z dnia 22 lipca 2014 r. o zmianie ustawy o zawodach pielęgniarki i położnej oraz niektórych innych ustaw" położne i pielęgniarki od 1 stycznia 2016 r. mogą „ordynować leki zawierające określone substancje czynne, z wyłączeniem leków zawierających substancje bardzo silnie działające, środki odurzające i substancje psychotropowe, oraz środki spożywcze specjalnego przeznaczenia żywieniowego, w tym wystawiać na nie recepty” [22], a także „ordynować określone wyroby medyczne, w tym wystawiać na nie zlecenia albo recepty (...) po uprzednim osobistym badaniu fizykalnym pacjenta" [22]. Uprawnione do tego będą położne i pielęgniarki, które posiadają dyplom ukończenia studiów drugiego stopnia na kierunku: pielęgniarstwo/położnictwo lub posiadające tytuł specjalisty w dziedzinie pielęgniarstwa lub położnictwa. Obowiązek ukończenia kursu specjalistycznego dotyczy osób, które w ramach kształcenia nie nabyły wiedzy objętej takim kursem [22]. Ponadto ustawa daje pielęgniarkom i położnym prawo do wystawiania skierowań na określone badania diagnostyczne, w tym diagnostyki laboratoryjnej, „z wyjątkiem badań wymagających metod diagnostycznych i leczniczych stwarzających podwyższone ryzyko dla pacjenta" [22].

Prawo w Polsce zmienia się na korzyść położnych. Możliwość prowadzenia przez nie ciąż fizjologicznych jest dużą szansą na podniesienie prestiżu własnego zawodu. To zwiększenie ich samodzielności, a tym sa- 
mym zadowolenia z wykonywanego zawodu mogłoby prowadzić do lepszego i efektywniejszego wykonywania pracy i być może zmniejszenia przypadków wypalenia zawodowego.

Wszystkie te zmiany bez wątpienia wpłynęłyby korzystnie na społeczeństwo, zwłaszcza na kobiety ciężarne i te, których ciąże przebiegają z powikłaniami - pacjentki. Taki „podział obowiązków” między położną i lekarzem, będący zarazem współpracą, a nie rywalizacją, gwarantowałby najlepszą opiekę dla ich podopiecznych, zgodną z najwyższymi standardami, profesjonalną i bezpieczną, powszechną i sprawdzoną już w wielu krajach.

W działania zmierzające do zmiany świadomości ciężarnych i społeczeństwa o kompetencjach położnych, zwłaszcza w zakresie prowadzenia ciąży fizjologicznej, powinno zaangażować się w jeszcze większym stopniu media. Reportaże i wywiady z położnymi, które w Polsce podjęły się otwarcia własnych gabinetów, oraz z ich podopiecznymi, opinie autorytetów w dziedzinie położnictwa, dokumenty nakręcone na podstawie opieki położniczej w innych państwach i tym podobne mogłyby przynieść niewątpliwe korzyści. Ponadto może warto, by w placówkach medycznych znalazły się ulotki promujące zawód i kompetencje położnych, a na tablicach ogłoszeń, oprócz praw pacjenta, zaczęły pojawiać się informacje na ten temat: szczegółowe wytyczne, badania naukowe potwierdzające najlepsze przygotowanie położnych do opieki nad ciężarną, system opieki w innych krajach itp.

Najważniejsze jednak jest to, by same położne znowu zaczęły wierzyć w siebie, swoją wartość, wiedzę, umiejętności i doświadczenie. By nauczyły się korzystać z przysługujących im praw i potrafiły sprzeciwić się w sytuacjach ich łamania. Wszak to właśnie położne przed wielu laty uważane były za specjalistki w dziedzinie fizjologii ciąży i porodu.

\section{Wnioski}

1. Ankietowane nie korzystają z usług położnych w zakresie prowadzenia ciąży fizjologicznej, a nawet nie wiedzą, że zgodnie z prawem polskim położne mogą prowadzić taką ciążę.

2. Ciężarne, które wiedzą o możliwości prowadzenia ciąży fizjologicznej przez położną, czerpią wiedzę z nieprofesjonalnych źródeł.

3. Respondentki nie zrezygnowałyby z prowadzenia ciąży przez lekarza na rzecz prowadzenia jej przez położną, nawet gdyby ciąża przebiegała fizjologicznie, ponieważ uważają, że położna nie ma wystarczającej wiedzy dotyczącej ciąży, porodu i połogu oraz nie jest odpowiednio przygotowana do prowadzenia ciąży.

4. Ciężarne, które zrezygnowałyby z prowadzenia ciąży przez lekarza na rzecz prowadzenia jej przez położną, zrobiłyby to, ponieważ uważają, że położna jest osobą odpowiednio przygotowaną do opieki nad ciężarną; istotną korzyścią związaną z prowadzeniem ciąży fizjologicznej przez położną jest dla ciężarnej możliwość zdobycia wiedzy na temat karmienia piersią oraz opieki nad noworodkiem.

\section{Piśmiennictwo}

1. Waszyński E. Rozwój położnictwa i ginekologii na świecie. W: tegoż, Historia położnictwa i ginekologii w Polsce. Wyd. II. Wrocław: Cornetis; 2012. 1-9.

2. Chwierot N, Leśniczak B, Krasomski G. Od prostej empatii do fachowej opieki położniczej. Położ Nauka Prakt. 2014; 1(25): 56-60.

3. Ćwiek D, Dzióbek I, Szymoniak K. Historia zawodu położnej na świecie. Położ Nauka Prakt. 2009; 4(8): 56-59.

4. Sznajder K, Mazurkiewicz B. Córki Ewy, czyli z historii zawodu położnej. Część 1. Położ Nauka Prakt. 2012; 2(18): 58-60.

5. Sznajder K, Mazurkiewicz B. Córki Ewy, czyli z historii zawodu położnej. Część 2. Rozwój położnictwa w czasach nowożytnych. Położ Nauka Prakt. 2012; 3(19): 60-63.

6. Ćwiek D, Daszkiewicz A, Branicka-Woźniak D. Historia kształcenia położnych i zdobywania samodzielności zawodowej w Polsce. Położ Nauka Prakt. 2010; 2(10): 62-66.

7. Sznajder K, Mazurkiewicz B. Córki Ewy, czyli z historii zawodu położnej. Część 3. Historia położnictwa w Polsce. Położ Nauka Prakt. 2012; 4(20): 46-50.

8. Felcenloben M. Szkoły położnych na ziemiach polskich w ujęciu historycznym. Położ Nauka Prakt. 2010; 4(12): $56-60$.

9. Kuś M, Bączek G. Położna powinna znać swoje miejsce. Mag Piel Położ. 2011; 5: 30-31.

10. Ustawa z dnia 15 lipca 2011 r. o zawodach pielęgniarki i położnej. Dz.U. z 2011 r. Nr 174, poz. 1039.

11. Pilucik B, Dzierżak-Postek E, Grzybowska K. Położna - zawód samodzielny? Mag Piel Położ. 2011; 12: 28-29.

12. Załącznik do Rozporządzenia Ministra Zdrowia z dnia 23 września 2010 r. w sprawie standardów postępowania oraz procedur medycznych przy udzielaniu świadczeń zdrowotnych z zakresu opieki okołoporodowej sprawowanej nad kobietą w okresie fizjologicznej ciąży, fizjologicznego porodu, połogu oraz opieki nad noworodkiem. Dz.U. z 2010 r. Nr 187, poz. 1259.

13. Agrawal P. Wytyczne NICE. Mag Piel Położ. 2011; 9: 30-31.

14. NICE confirms midwife - led care during labour is safest for women with straightforward pregnancies, http://www.nice. org.uk/news/press-and-media/midwife-care-during-laboursafest-womenstraightforward-pregnancies (data dostępu: 23.05.2016).

15. University of Minnesota: Greater access to midwifery care may improve communication between pregnant women and their health care providers finds University of Minnesota study, http://www.health.umn.edu/news-releases/greater-access-midwifery-care-may-improve-communication-between-pregnant-women-and (data dostępu: 23.05.2016).

16. Bilińska E, Bączek G, Dmoch-Gajzlerska E. Medykalizacja porodu - przegląd piśmiennictwa. Położ Nauka Prakt. 2013; 2(22): 8-13.

17. Wieczorkowska M. Medykalizacja społeczeństwa w socjologii amerykańskiej. Prz Socjolog. 2012; 61(2): 34. 
18. Grychtoł S, Leszczyńska K. Stereotypy a pozycja zawodowa. Mag Piel Położ. 2012; 10: 4-5.

19. Emons JK, Luiten MIJ. Opieka położnicza w Europie: raport z piętnastu krajów członkowskich Unii Europejskiej. Warszawa: Fundacja Rodzić po Ludzku; 2002. 61.

20. Petersem J. Samodzielność zawodowa położnych w Królestwie Duńskim. Mag Piel Położ. 2011; 1-2: 66-67.

21. Dudzińska-Petersem J. Kto doceni położną? Mag Piel Położ. 2013; 4: 22-23.

22. Ustawa z dnia 22 lipca 2014 r. o zmianie ustawy o zawodach pielęgniarki i położnej oraz niektórych innych ustaw. Dz.U. z 2014 r., poz. 1136, http://isap.sejm.gov.pl (data dostępu: 23.05.2016).
Artykuł przyjęty do redakcji: 12.05.2017

Artykuł przyjęty do publikacji: 27.12.2017

Źródło finansowania: Praca nie jest finansowana z żadnego źródła. Konflikt interesów: Autorzy deklarują brak konfliktu interesów.

Adres do korespondencji:

Anna Leja-Szpak

ul. Piotra Michałowskiego 12

31-126 Kraków

tel.: 126333497 w. 33

e-mail: a.leja-szpak@uj.edu.pl

Zakład Fizjologii Medycznej, Instytut Fizjoterapii

Wydział Nauk o Zdrowiu

Uniwersytet Jagielloński - Collegium Medicum 